\title{
PERINATAL OUTCOME OF PRETERM INFANTS IN FEDERATION OF BOSNIA AND HERZEGOVINA
}

\author{
Skokic Fahrija, ${ }^{1}$ Hotić Nesad, ${ }^{1}$ Muratovic Selma, ${ }^{2}$ Skokic Maida, ${ }^{1}$ Hadzic Devleta, ${ }^{1}$ \\ Cosickic Almira, ${ }^{1}$ Selimovic Amela, ${ }^{1}$ Zulic Evlijana, ${ }^{1}$ Meric Alma, Halilbasic Amir ${ }^{1}$ \\ ${ }^{1}$ Paediatric Clinic, University Clinical Centre Tuzla, Faculty of Medicine Tuzla, Bosnia and Herzegovina \\ ${ }^{2}$ Gynaecology and Obstetrics Clinic, University Clinical Centre Tuzla, Faculty of Medicine Tuzla, \\ Bosnia and Herzegovina
}

Primljen/Received 30. 01. 2015. god.

Abstract: Introduction: Despite growing progress of perinatal medicine and perinatal care, between $9-19 \%$ of preterm infants are born each year. Improvement in survival of infants and the reduction in infant mortality rates is a key role of perinatal quality healthcare.

The Aim: To evaluate the perinatal outcome of preterm infants in maternity wards of the Federation of Bosnia and Herzegovina for a period of one year.

Material and methods: Of 22897 live newborns, the research criteria matched 669 (2.9\%) preterm infants with complete medical records in ten cantons of the Federation Bosnia and Herzegovina. We analyzed data from maternity wards documentation and discharge letters from tertiary health care centers.

Results: Most deliveries were in the Tuzla and Sarajevo Canton with $42.5 \%$ of preterm infants. The mean gestational age of preterm infants was 31.4 weeks, with $\mathrm{SD} \pm 5.34$, and the mean birth weight 1295 grams, $\mathrm{SD} \pm$ 234.2. The mean Apgar score was $4.6 \pm 2.1$, and in the fifth minute $6.6 \pm 1.9$. Of 669 examinees, there were 345 $(51.56 \%)$ males and $324(48.44 \%)$ females (51.56 vs $48.44 ; \chi^{2}=1.19 ; \mathrm{P}=0.27$ ). By analyzing the frequency of preterm infant birth rate according to weight categories, we found a significant difference in some levels of perinatal health institution, between the $1^{\text {st }}$ and $2^{\text {nd }}$ institutions levels ( $1.76 \%$ vs $3.01 \%$; $\mathrm{P}<0.0001)$, also between $2^{\text {nd }}$ and $3^{\text {rd }}$ institutions levels $(3.01 \%$ vs $3.03 \%$; $\mathrm{P}<$ $0.0002)$, and between 1st and 3rd institutions levels $(1.76 \%$ vs $3.03 \% ; \mathrm{P}<0.0001)$. A significant statistical difference in survival of tested newborns was found in institutions of 3rd level $\chi^{2}=49.25 ; \mathrm{P}<0.0001$ with a low risk for unfavorable outcome $[\mathrm{OR}=0.436 ; 95 \% \mathrm{CI}$ (0.346-0.550)].

Conclusion: Perinatal outcome of preterm infants in the Federation Bosnia and Herzegovina significantly
Prihvaćen/Accepted 28. 02. 2015. god.

depends on the level of perinatal health care. Survival rate of infants born in the institutions of the 3rd level was statistically much higher than the survival rate of infants who were born in the $1^{\text {st }}$ and the $2^{\text {nd }}$ level institutions.

Key words: preterm infants, perinatal outcome, preterm birth, regionalization, neonatal mortality.

\section{INTRODUCTION}

Preterm birth is the most common complication of the second half of pregnancy and preterm labour itself is associated with a higher risk of medical complication for mother and child. Due to high perinatal rate mortality (60-80\%), preterm labour is one of the most important problems of modern medicine (1). The chances for preterm infants' survival probability is several times less compared to chances for survival of a full term infants. Either they do not survive, or if they survive, they have significant chances to suffer from disabilities. In addition to a various fetal complications that may occur during pregnancy and labour, premature infant with its immature organs and organ systems is being exposed to a greater risk for early and late neonatal complications that occur while adjusting the life outside the uterus. Regionalization of perinatal care, improving technology, and better understanding of the pathopsychology of preterm infants and their specific needs made a significant increase in the preterm infants survival rate (2). Preterm born infant has a real chance of survival if born at a gestational age 26-28 weeks or weighing 800-1000 grams, although the application of surfactants and new mechanical ventilation options increase the cances of survival. Preterm is defined as infant born at a gestational age before 37 weeks, and its 
weight is important at any time of pregnancy (3). Particulary vulnerable are infants, $15 \%$ of them, with primary immaturity and signs of intrauterine growth restriction (4). Total mortality for this group of infants is $12.1 \%$, and there is increase in the incidence of respiratory distress syndrome, intracranial hemorrhage, premature retinopaty and necrotizing enerocolitis. The influence of certain factors such are male, twin pregnancy, hypothermia and sepsis increase the risk. Mortality and morbidity of preterm infants is significantly higher in smaller perinatal centers (5). Improvement in survival rate of newborn infants and the reduction in infant mortality rate is a key role of perinatal quality healthcare. It is common that the total mortality rate of a newborns in the region or country is being expressed by groups of birth weight and gestational age. However, by comparing the possibility of survival, it is clear that the infant with the same birth weight will have a greater chance of survival if not seriously ill ( if e.g. do not develop respiratory distress or if there is no life-threatening anomaly) (6).

Among other criteria, the success of neonatal institution is often measured by mortality rate and survival rate of patients. In these comparisons, newborns are usually stratified by outcome predictors, most commonly by a birth weight, and later there are comparable groups of patients from different neonatal institutions. Some studies have been adjusted to the differences between birth weight and other prognostic characteristic in treated infants. They showed great differences in mortality rates in the third level health institutions and a lower- level neonatal institutions (7).

The existence of differences in medical practice and outcome of patients badly effects the credibility of medicine. That is why reducing these differences is one of priorities in the system of organized health care. The outcome of patients is in a function of health care quality, but it is subjected to other influences, even accidental, but it is also a function of the clinical characteristic of patiens, including the severity of disease.

Diseases severity is defined and measured by quantifying the deviation from the physiological and/or the presence of a pathological condition and/or the presence and intensity of the disease. To compare the outcomes of patients between individual neonatal institutions, it is necessary to stratify cases by severity of disease in these institutions. The comparison of neonatal institutions is only possible by the outcome of stratified patients. To this end, a research project of risk- adjusted outcomes is carried out. This is the processs of classifying subjects of compared groups into various classes of risk to compare outcomes separately for each class. This approach allows better comparation of groups, and it is inevasible while analysing the patients outcome when it is difficult or impossible to do the randomization of group of patients, such as in the cases of exploring hospitals possibilities, differences in clinical practice, health care organization in the region, outcome trends through time period, resources using, health care services financing etc. Survival rate on infants with birth weight less than 1500 grams until the moment of discharge from hospital $(\mathrm{N}=514)$ in a period 1996-2001 in one of neonatal institution of the third level in the Czech Republic was $90.7 \%$, and for the group of infants of birth weight 1000-15000 grams ( $=$ 321 ) was $98.8 \%(8)$. In a group of patients of other neonatal institutions in the Czech Republic, survival rate of infants of birth weight less than 1000 grams by the time of discharge from hospital in a period 1996-2001 was $77 \%$, while in Norway, in a similar period, was $89 \%(9)$.

Despite growing progress of perinatal medicine and perinatal care, between $9-19 \%$ of premature infants are born each year. It is estimated that more than $95 \%$ of preterm infants are being born in developing countries, with birth incidence of $16.5 \%$, among stillborns even 20\%, without a tendency of decrease (10). Also, there is no a tendency of decrease in neonatal morbidity, mortality neuromotor impairments, cerebral palsy with incidence between 1 and 2/1000 live births in general population (10). A lower birth weight, shorter gestational age and low frequency of antenatal steroid administration, as well as "air leak syndrome" are associated with a higher risk of death. Survival rate is higher and morbitity rate is lower if the place of birth is maternity ward of the third level rather than elsewhere. Recent years have seen marked changes in the general approach to the management of preterm infants bringing a significant contribution to a higher survival rate, lower morbidity and lower prevalence of disability. There is a higher rate of labours of such infants in the marternity wards of third level, prenatal corticosteroids administration, wider use of high- quality ventilators and incubators, surfactants and early pharmacological closure of ductus arteriousus in preterm infants.

The progress of regionalization of perinatal care increased the ratio of infants' birth less than 1500 grams born in maternity hospitals of the third level, and reduced the number of births in maternity hospitals of the first and second level. The research from the beginning of the process of regionalization of perinatal care in the USA has shown that during the two four- year periods brought an increase in the proportion of infants born with birth weight of 454-1820 grams in the maternity wards of the third level and the decrease in the proportion among infants born in the maternity ward of the first level, while the proportion of infants born in the maternity wards of the second level remained un- 
changed (10). Caring for a preterm infant takes a lot of specific care, and today the treatment and care are directed to specialized tertiary care centers, favouring inutero transport. Perinatal and neonatal health care in the $\mathrm{F} \mathrm{B \& H}$ is not regionalized. Antenatal transport transport of patients is left to the personal initiative of a doctor on the field. Postnatal transport is carried out "from itself" instead of "to itself". Based on global experience and situation assesment in the $\mathrm{F} \& \mathrm{H}$, there are only a few working groups for perinatal medicine and the implementation of the regional perinatal care organization (11). The aim of this paper is to evaluate the perinatal outcome of preterm infants in maternity wards of the Federation of Bosnia and Herzegovina for a period of one year.

\section{PATIENTS AND METHODS}

This paper presents and analyzes the results of retrospective study which evaluated preterm birth incidence in the cantons of the Federation of Bosnia and Herzegovina, according to the levels of the maternity wards in which they were born. Also, this paper analyzes overall survival rate of infants and compares the subgroups of birth weight and the levels of maternity wards. The research place is the Federation of Bosnia and Herzegovina, which is administratively divided into ten cantons (Figure 1).

As an infant we took every child born up to $36+6$ weeks of pregnancy and birth weight of 2500 grams and less. All the pregnancies of whom are preterm infant born were single, and the infants were divided into the soubgroups according to birth weight (500-999 grams, 1000-1449 grams, 1500-1999 grams, 2000-2499 grams),

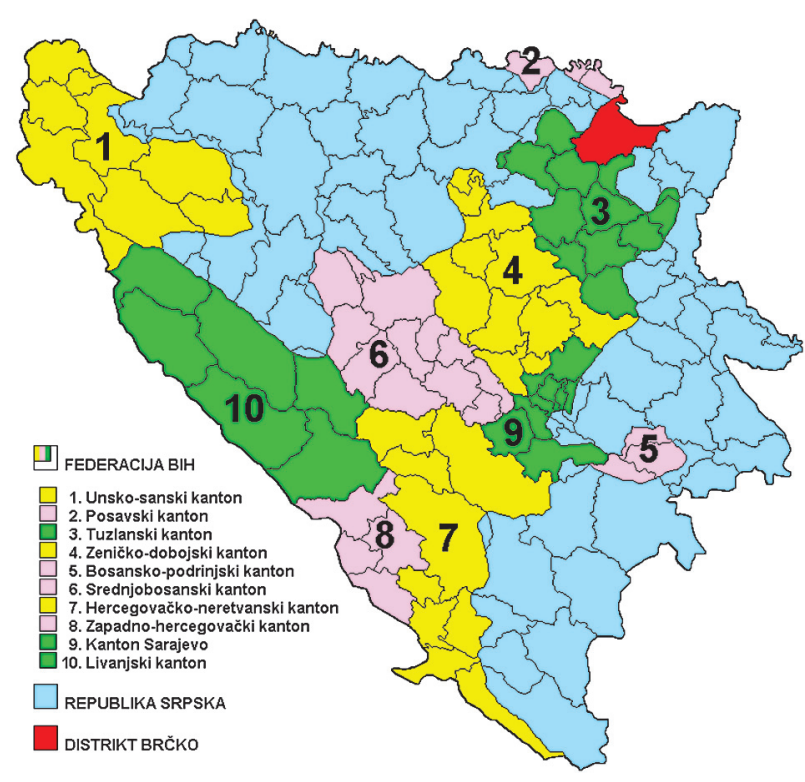

Figure 1. Cantons in the Federation of Bosnia and Herzegovina adding that there were no livebirth preterm infants with birth weight less than 500 grams. Of total 22897 infants, these terms met $669(2,9 \%)$ of them. We analyzed data from the maternity wards and discharge letters from the tertiary health care centers. For the purposes of this study, the levels of neonatal units are defined according to diagnostic and therapeutic capabilities, and all according to the definition of the Association of Neonatologists of the FB\&H from 2000 (11).

The regional distribution of maternity wards and neonatal units followed the current situation of the organization and the common practice of postnatal transport:

- first level - capacity to care for eutrophic term newborns,

- second level - capacity to care for term newborns with hyperbilirubinemia, hypoglicemia and acidosis,

- third level - capacity to care for newborns with various health problems of any gestational age and birth weight, including mechanical ventilation, exanguinotransfusion, and all surgical procedures except cardio surgical.

In some cantons there are only maternity wards without neonatal institution, so that the place of birth and health care for newborns are being marked as perinatal health institutions (PHI) according to the leves.

The data were analyzed by the $\chi^{2}$ test in the contingency 2 by 2 tables. The data were shown according to the level of perinatal care. The results of the logistic models were expressed as odds ratios (OR) with 95\% confidence intervals (CI). Those infants who were born at the lower level of care were identified and their outcome was presented as number of transported infants with early neonatal mortality rate. Statistical analysis was performed with SAS software, version 9.1 (SAS Institute, Cary, NC). $\mathrm{P}<0.05$ was considered statistically significant.

\section{RESULTS}

The examined infants are born in a period $1^{\text {st }} \mathrm{Janu}$ ary 2014 to $31^{\text {st }}$ December 2014, in the FB\&H. The highest birth rate was in the biggest two cantons, the Tuzla and Sarajevo Canton, where $42.5 \%$ of total preterm infants in the FB\&H were born. The remaining $18.3 \%$ of infants were born in the Zenica- Doboj Canton, $12.5 \%$ of infants in the Una- Sana Canton, $10.8 \%$ in the Central Bosnia Canton, and $15.9 \%$ in other cantons of the FB\&H. The total sample included 669 preterm infants who had a birth weight less than 2500 grams. The range of birth weight was 500 to 2499 grams, with an average birth weight of 1295 grams, SD \pm 234 .2, while an average gestational age was 31.4 gestational weeks with $\mathrm{SD} \pm 5.34$. 
The average age of mothers of 661 preterm infants was 27.7 years $(\mathrm{SD} \pm 1.2)$, and ranged 16 to 38 years. Out of 669 mothers of an infants examined, the data on mother's age were not available for $8(1.2 \%)$, and the data on Apgar score were not available for 154 (23\%) infants.

The mean Apgar score in the first minute was 4.6 \pm 2.1 , and in the fifth minute $6.6 \pm 1.9$. Of 669 tested infants, 345 (51.56\%) were male, and the remaining 324 $(48.44 \%)$ were female, with a male: female ratio of 1.06:1. Male newborns were not statistically more prevalent ( 51.56 vs $48.44 ; \chi^{2}=1.19 ; \mathrm{P}=0.27$ ). The data on gender distribution are shown in Figure 2.

$411(61.4 \%)$ of the tested preterm infants were born by a normal childbirth, and 141 (21.1\%) preterm infants were operatively born with statisticaly significant difference $\left(\chi^{2}=344.32 ; \mathrm{P}<0.0001\right)$. There were no available data on the methods of childbirth for 63 (9.4\%) preterm infants.

The analysis of the tested newborns by 500 grams- birth weight subgroups has shown that the biggest number of the tested newborns was in the subgroup of the biggest birth weight of $2000-2499$ grams, 307 of them $(45.9 \%)$, while the smallest number was found in 500-999 grams subgroup, 49 of them (7.3\%).

By analyzing the frequency of births of tested infants according to weight groups, we have found a significant difference in certain levels of PHI, as shown in Figure 1. In the total sample of tested newborns, statistically significant difference was found in the distribution of birth of tested between $1^{\text {st }}$ and $2^{\text {nd }}$ level of PHI $(1.76 \%$ vs $3.01 \% ; \mathrm{P}<0.0001)$, thereafter between $2^{\text {nd }}$ and $3^{\text {rd }}$ level of PHI (3.01\% vs $3.03 \%$; $\left.<0.0002\right)$, and between $1^{\text {st }}$ and $2^{\text {nd }}$ level of PHI $(1.76 \%$ vs $3.03 \%$; $\mathrm{P}<$ $0.0001)$.

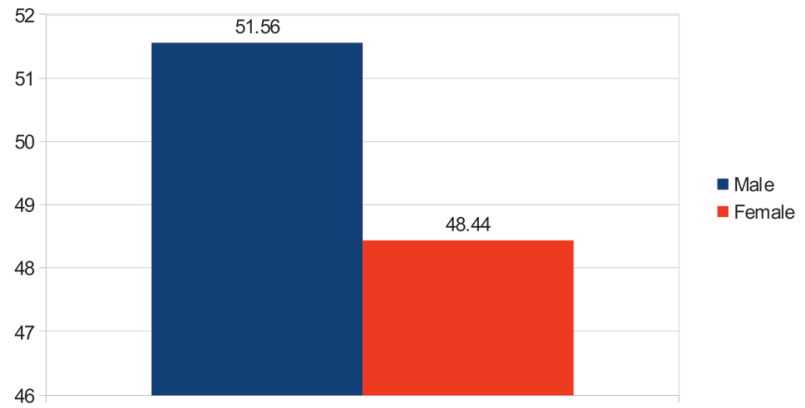

Figure 2. Gender distribution of tested newborns

$10 \%$ of the tested infants in weight group 500-999 grams was in the $1 \mathrm{st}$ level of PHI, $4.2 \%$ of the tested infants from this subgroup was in the $2^{\text {nd }}$ level of PHI, and $9.6 \%$ infants in the $3^{\text {rd }}$ level of PHI. Statistically significant difference was found between the $2^{\text {nd }}$ and $3^{\text {rd }}$ level of PHI ( $4.2 \%$ vs $9.65 ; \mathrm{P}=0.01)$. The difference was found in a weight group of 1000-1499 grams $(12.9 \%$ vs $20.3 \% ; P=0.01)$. Statistically significant difference in the frequency of births between the $2^{\text {nd }}$ and $3^{\text {rd }}$ level of perinatal health institution (PHI) was found in the biggest weight group of newborns 2000-2499 grams $\left(\chi^{2}=24.21 ; \mathrm{P}<0.0001\right)$.

In the 1st level of PHI, $48 \%$ of infants were in the biggest weight group of 2000-2499 grams. This weight group of infants was the most represented in the $2^{\text {nd }}$ level of PHI $60.1 \%$, while in the $3^{\text {rd }}$ level of PHI this group was slightly less represented $40.9 \%$ (Figure 3 ).

Extremely premature infants of 22 to 32 gestation weeks accounted for one-third of the tested infants $(219 ; 32.7 \%)$, while moderately premature infants were the least represented $-25.7 \%$.

By analyzing the frequency of tested newborns according to a gestational age, we have found a significant difference in certain leves of PHI, as shown in Figure 2.

Table 1. Distribution of preterm infants birth according to weight groups and the level of perinatal institutions

\begin{tabular}{|c|c|c|c|c|c|c|}
\hline Birth weight & $\begin{array}{c}\mathrm{PHI}^{+} \\
1^{\text {st }} \text { level } \\
\mathrm{N} / \%\end{array}$ & $\begin{array}{c}\text { PHI } \\
2^{\text {nd }} \text { level } \\
\text { N/\% }\end{array}$ & $\begin{array}{c}\text { PHI } \\
3^{\text {rd }} \text { level } \\
\text { N/\% }\end{array}$ & $\begin{array}{c}\chi^{2} \mathrm{P} \\
\mathrm{PHI} \\
1^{\text {st }} / 2^{\text {nd }}\end{array}$ & $\begin{array}{c}\chi^{2} \mathrm{P} \\
\mathrm{PHI} \\
2^{\text {nd }} / 3^{\text {rd }}\end{array}$ & $\begin{array}{l}\chi^{2} \mathrm{P} \\
\mathrm{PHI} \\
1^{\mathrm{st}} / 3^{\text {rd }}\end{array}$ \\
\hline 500-999 & $3(10.4 \%)$ & $12(4.2 \%)$ & $34(9.6 \%)$ & $\begin{array}{c}\chi^{2} 1.04 \\
\text { P } 0.30\end{array}$ & $\begin{array}{c}\chi^{2} 6.26 \\
\text { P } 0.01\end{array}$ & $\begin{array}{c}\chi^{2} 0.01 \\
\text { P } 0.89\end{array}$ \\
\hline 1000-1449 & $3(10.4 \%)$ & $37(12.9 \%)$ & $72(20.3 \%)$ & $\begin{array}{c}\chi^{2} 0.01 \\
P 0.91\end{array}$ & $\begin{array}{c}\chi^{2} 5.62 \\
\text { P } 0.01\end{array}$ & $\begin{array}{c}\chi^{2} 1.12 \\
P 0.28\end{array}$ \\
\hline 1500-1999 & $9(31 \%)$ & $63(22 \%)$ & $103(29.1 \%)$ & $\begin{array}{c}\chi^{2} 0.75 \\
\text { P } 0.38\end{array}$ & $\begin{array}{c}\chi^{2} 3.75 \\
P 0.52\end{array}$ & $\begin{array}{c}\chi^{2} 0.00 \\
\text { P } 0.99\end{array}$ \\
\hline 2000-2499 & $14(48.3 \%)$ & $174(60.1 \%)$ & $145(40.9 \%)$ & $\begin{array}{c}\chi^{2} 1.24 \\
P 0.26\end{array}$ & $\begin{array}{l}\chi^{2} 24.21 \\
P 0.0001\end{array}$ & $\begin{array}{c}\chi^{2} 0.32 \\
P 0.56\end{array}$ \\
\hline TOTAL & $29(1.76 \%)$ & $286(3.01 \%)$ & $354(3.03 \%)$ & $\begin{array}{l}\chi^{2}=272.1 \\
P<0.0001\end{array}$ & $\begin{array}{l}\chi^{2}=13.4 \\
P<0.0002\end{array}$ & $\begin{array}{l}\chi^{2}=548.1 \\
P<0.0001\end{array}$ \\
\hline
\end{tabular}

${ }^{+} \mathrm{PHI}$ - perinatal healthcare institution 
Table 2. Distribution of the births of a low-birth weight infants according to a gestational age and the level of perinatal institution in the $F B \& H$

\begin{tabular}{|c|c|c|c|c|c|c|}
\hline $\begin{array}{c}\text { Gestational } \\
\text { age }\end{array}$ & $\begin{array}{c}\text { PHI } \\
1^{\text {st }} \begin{array}{l}\text { level } \\
\mathrm{N} / \%\end{array}\end{array}$ & $\begin{array}{c}\text { PHI } \\
2^{\text {nd }} \text { level } \\
\mathrm{N} / \%\end{array}$ & $\begin{array}{c}\text { PHI } \\
3^{\text {rd }} \text { level } \\
\mathrm{N} / \%\end{array}$ & $\begin{array}{c}\chi^{2} \mathrm{P} \\
\mathrm{PHI} / \mathrm{II}\end{array}$ & $\begin{array}{c}\chi^{2} \mathrm{P} \\
\mathrm{PHI} \text { II } / \mathrm{III}\end{array}$ & $\begin{array}{c}\chi^{2} \mathrm{P} \\
\mathrm{PHI} / \mathrm{III}\end{array}$ \\
\hline $22-26$ & $0(\%)$ & $5(1.7 \%)$ & $17(4.8 \%)$ & $\begin{array}{c}\chi^{2}=6.4 \\
\mathrm{P}<0.01\end{array}$ & $\begin{array}{c}\chi^{2}=11 \\
\mathrm{P}<0.0009\end{array}$ & $\begin{array}{c}\chi^{2}=30.11 ; \\
\mathrm{P}<0.0001\end{array}$ \\
\hline $27-29$ & $2(6.9 \%)$ & $23(8.5 \%)$ & $49(13.8 \%)$ & $\begin{array}{c}\chi^{2}=32 \\
\mathrm{P}<0.0001\end{array}$ & $\begin{array}{c}\chi^{2}=17.36 ; \\
\mathrm{P}<0.0001\end{array}$ & $\begin{array}{c}\chi^{2}=82.98 ; \\
\mathrm{P}<0.0001\end{array}$ \\
\hline $30-32$ & $5(17.24 \%)$ & $53(18.5 \%)$ & $66(18.6 \%)$ & $\begin{array}{c}\chi^{2}=76.17 ; \\
\mathrm{P}<0.0001\end{array}$ & $\begin{array}{c}\chi^{2}=2.42 ; \\
\mathrm{P}=0.11\end{array}$ & $\begin{array}{c}\chi^{2}=101.4 ; \\
\mathrm{P}<0.0001\end{array}$ \\
\hline $33-36$ & $7(24.1 \%)$ & $84(29.3 \%)$ & $96(27.1 \%)$ & $\begin{array}{c}\chi^{2}=126.94 ; \\
\mathrm{P}<0.0001\end{array}$ & $\begin{array}{c}\chi^{2}=1.34 ; \\
\mathrm{P}=0.24\end{array}$ & $\begin{array}{c}\chi^{2}=150.3 ; \\
\mathrm{P}<0.0001\end{array}$ \\
\hline Less 37 & $15(51 \%)$ & $121(42.3 \%)$ & $126(35.6 \%)$ & $\begin{array}{c}\chi^{2}=162.13 ; \\
\mathrm{P}<0.0001\end{array}$ & $\begin{array}{c}\chi^{2}=0.12 ; \\
\mathrm{P}=0.71\end{array}$ & $\begin{array}{c}\chi^{2}=171.6 ; \\
\mathrm{P}<0.0001\end{array}$ \\
\hline TOTAL & $29(1.76 \%)$ & $286(3.01 \%)$ & $354(3.03 \%)$ & $\begin{array}{c}\chi^{2}=272.1 ; \\
\mathrm{P}<0.0001\end{array}$ & $\begin{array}{c}\chi^{2}=13.4 ; \\
\mathrm{P}<0.0002\end{array}$ & $\begin{array}{c}\chi^{2}=548.1 ; \\
\mathrm{P}<0.0001\end{array}$ \\
\hline
\end{tabular}

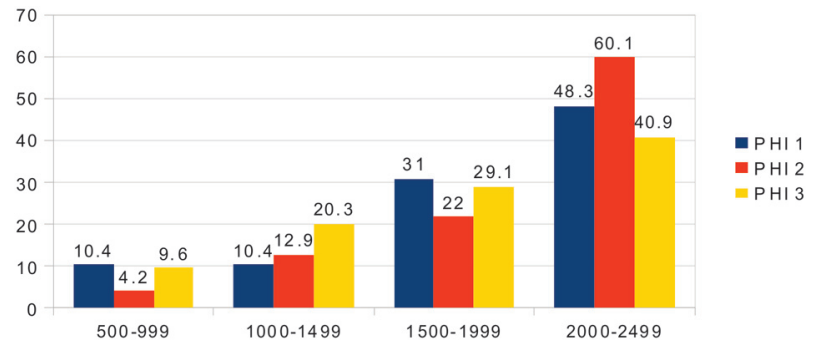

Figure 3. Distribution of preterm infants births according to a weight groups and perinatal health care institution level

The frequency of preterm infant births was significally different also according to a gestational age in comparison of the first level of PHI with the second and third level of PHI, but there were no statistically significant diference between the second and third level of perinatal health institution when about a gestational age 30-32 weeks $\left(\chi^{2}=2.42 ; \mathrm{P}=0.11\right)$, also when about a gestational age $33-35$ weeks $\left(\chi^{2}=1.34 ; \mathrm{P}=0.24\right)$.

The options of primary and definite health care in PHI of cantons in the Federation of Bosnia and Herzegovina are limited. More than $47 \%$ of a low- birth weight infants was born in the first and second level of PHI, while 53\% was born in the third level of PHI in the corresponding neonatal intensive care unit in the FB\&H. The outcome of the tested infants was followed through the survival rate, early neonatal and total neonatal mortality rate, because these are clear indicators of perinatal care.

The early neonatal mortality rate of the tested infants in the first level of PHI was the lowest (1.8\%), in the second level of PHI was the biggest (5.6\%), and in
Table 3. The rate of early neonatal mortality of the tested infants according to the levels of perinatal health institutions in the Federation of Bosnia and Herzegovina in 2009

\begin{tabular}{|c|c|c|}
\hline $\begin{array}{c}\text { Level } \\
\text { of PHI }\end{array}$ & $\begin{array}{c}\text { Died preterm } \\
\text { infants in the first } \\
\text { seven days }\end{array}$ & $\begin{array}{c}\text { The early neonatal } \\
\text { mortality rate }\end{array}$ \\
\hline I & $3 / 1651$ & $1.8 \%$ o \\
\hline II & $53 / 9490$ & $5.6 \%$ o \\
\hline III & $52 / 11666$ & $4.5 \%$ o \\
\hline TOTAL & $108 / 22807$ & $(4.7 \%$ ) \\
\hline
\end{tabular}

$\left(\chi^{2}=0,71 ; \mathrm{P}=0,398\right) ;[\mathrm{RR}=0,507(95 \% \mathrm{CI} 0.148-1.738)]$ PZU of the first and second level.

$\left(\chi^{2}=71,8 ; \mathrm{P} \mathrm{P}<0,0001\right) ;[\mathrm{RR}=6,349(95 \%$ CI $4.030-10.003)]$ PZU of the second and third level.

the third level of PHI was $4.5 \%$. Although the percentage of deaths within the first seven days among the tested infants from the second level of PHI (5.6\%) was higher compared to the first level, the difference was not statistically significant, with an equal relative risk for fatal outcome $\left(\chi^{2}=0.71 ; \mathrm{P}=0.398\right)$; $[\mathrm{RR}=0.507$ (95\% CI 0.148-1.738)]. Analogous to this, we compared the rate of early nenonatal deaths of the second and third level $(5.6 \%$ vs $4.5 \%$; $\mathrm{P}<0.0001)$ and found statistically significant difference $\left(\chi^{2}=71.8 ; \mathrm{P}<0.0001\right)$; $[\mathrm{RR}=6.349(95 \% \mathrm{CI} 4.030-10.003)]$ with a high relative risk for fatal outcome in the second level of PHI.

$108 / 669(16.1 \%)$ of the tested infants died during the early neonatal period, so the total rate of early neonatal mortality in all three PHI was 4.7 per 1000 live births. 
Table 4. The outcome of the tested infants according to the level of perinatal health institutions and the treatment in the Federation of Bosnia and Herzegovina

\begin{tabular}{|c|c|c|c|c|}
\hline $\begin{array}{c}\text { Level } \\
\text { of PHI }\end{array}$ & $\begin{array}{c}\text { The number } \\
\text { of infants born } \\
\mathrm{N} / \%\end{array}$ & $\begin{array}{c}\text { The number } \\
\text { of treated infants } \\
\mathrm{N} / \%\end{array}$ & $\begin{array}{c}\text { The number } \\
\text { of survived infants } \\
\mathrm{N} / \%\end{array}$ & $\begin{array}{c}\text { The number of died } \\
\text { infants in the first } \\
7 \text { days of life } \\
\text { N/\% }\end{array}$ \\
\hline I & $29(4.3 \%)$ & $3(0.5 \%)$ & 0 & $3(2.8 \%)$ \\
\hline II & $286(42.8 \%)$ & $127(19.7 \%)$ & $54(10.5 \%)$ & $53(49 \%)$ \\
\hline III & $354(52.9 \%)$ & $513(79.8 \%)$ & $461(89.5 \%)$ & $52(49.2 \%)$ \\
\hline TOTAL & $669(100 \%)$ & $643(100 \%)$ & $515(100 \%)$ & $108(100 \%)$ \\
\hline
\end{tabular}

$\left(\chi^{2}=0,71 ; \mathrm{P}=0,398\right)$ PHI of the first and second level

$\left(\chi^{2}=71,8 ; \mathrm{P}<0,0001\right)$ PHI of the second and third level

Table 5. The outcome of the tested infants by the end of 28 days of life in the Federation of Bosnia and Herzegovina

\begin{tabular}{|c|c|c|c|}
\hline & $\begin{array}{c}\text { Died infants } \\
\text { to } 28 \text { days of life }\end{array}$ & $\begin{array}{c}\text { Survived infants } \\
\text { to } 28 \text { days of life }\end{array}$ & $\begin{array}{c}\chi^{2} \mathrm{P} \\
\text { OR 95\%CI }\end{array}$ \\
\hline I & $3 / 669(0.4 \%)$ & 0 & $\begin{array}{c}\chi^{2}=1.86 ; \mathrm{P}=0.171 \\
\text { OR }=1.125 ; 95 \% \mathrm{CI} \\
(0.923-1.678)\end{array}$ \\
\hline II & $112 / 669(16.7 \%)$ & $93 / 669(13.9 \%)$ & $\begin{array}{c}\chi^{2}=49.25 ; \mathrm{P}<0.0001 \\
\text { OR }=0.436 ; 95 \% \mathrm{CI} \\
(0.346-0.550)\end{array}$ \\
\hline III & $169 / 669(25.3 \%)$ & $292 / 669(43.6 \%)$ & $\chi^{2}=29.89 ; \mathrm{P}<0.0001$ \\
\hline TOTAL & $284 / 669(42.4 \%)$ & $385 / 669(57.5 \%)$ & \\
\hline
\end{tabular}

In the study period, $42.4 \%$ of the tested infants had died, while $57.5 \%$ survived. When compared to the ratios died: survived, it was found statistically significant difference $\left(\chi^{2}=29.89 ; \mathrm{P}<0.0001\right)$.

As can be seen from the table, there were no survived infants in the first level of PHI during the first seven days of life. In the second level of PHI there were 10.5\% of survived infants during the first seven days of life. In the study, we compared the survival rate between the first and second levels of PHI. Although the percentage of survived infants in the second level of PHI was $10.5 \%$, the difference was not statistically significant $\left(\chi^{2}=0.71 ; \mathrm{P}=\right.$ 0.398). Analogous to this, we compared the survival rate of the tested infants in the third level of PHI, where $89.5 \%$ infants survived during the first seven days of life, with the survival rate in the second level of PHI $(89.5 \%$ vs $\left.10.5 \% ; \chi^{2}=71.8 ; \mathrm{P}<0.0001\right)$, and it was found statistically significant difference.

By the end of the first month of life (up to 28 days of life) another $176(26.3 \%)$ infants had died. There was a total of $284 / 669(42.4 \%)$ deaths of the tested infants.

During the study period, $42.4 \%$ of the tested infants had died, and $57.5 \%$ survived in total. Compared

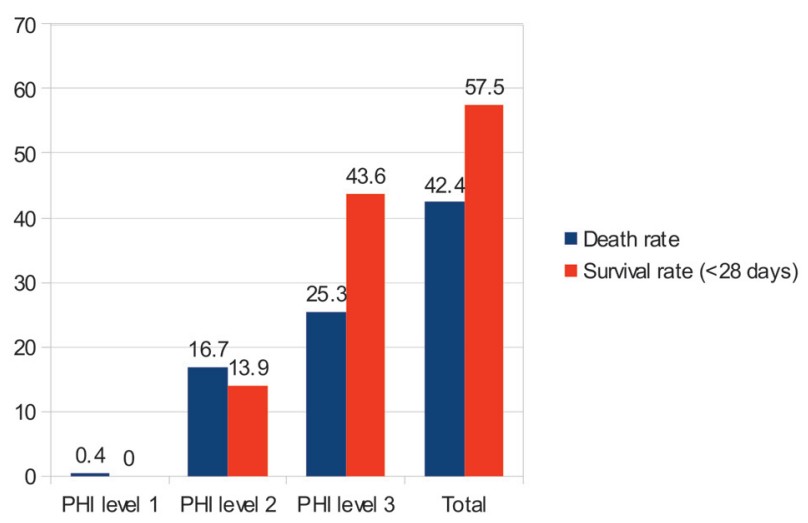

Figure 4. The outcome of the tested infants by the end of 28th day of life in the Federation of Bosnia and Herzegovina

to died: survived, we found statistically significant difference $\left(\chi^{2}=29.89 ; \mathrm{P}<0.0001\right)$.

Out of 669 newborns, $112(16.7 \%)$ of them died in the second level of PHI, while 93 (13.9\%) survived. The difference was not statistically significant $\left(\chi^{2}=\right.$ $1.86 ; \mathrm{P}=0.171)[\mathrm{OR}=1.125 ; 95 \% \mathrm{CI}(0.923-1.678)]$ and the risk for a favorable and unfavorable outcome is equal. 
Statistically significant difference in survival rate of the tested infants was found in the third level of PHI $\chi^{2}=49.25 ; \mathrm{P}<0.0001$ with a low risk for unfavorable outcome $[\mathrm{OR}=0.436 ; 95 \% \mathrm{CI}(0.346-0.550)]$.

\section{DISCUSSION}

In 10 cantons of the $\mathrm{FB} \& \mathrm{H}$ in the period from 01 . 01. to 31. 12. 201422897 infants were born of whom 11 liveborn infants had birth weight below 500 grams, which was the exclusion criterion. The total population of 22897 infants was left of whom 669 (2.9\%) were preterm infants. Rate in the FB\&H is relatively low in the comparison with other countries where it ranges from 3.3 to $38 \%$. Prematurity and LBW (low birth weight) rates are particularly high in Asia and sub-Saharan countries. In Burkina Faso, it is estimated that $19 \%$ of all live births in 1999-2005 were LBW. An estimated 20\% of infants are born prematurely in Bangladesh, $30 \%$ of whom are LBW. Perinatal outcome is the indicator of the quality of perinatal care. Prematurity and LBW is a public health problem, and complicates around $17 \%$ of all births. It is among the major mortality risk factors in early infancy (12).

Majority of preterm infants were born in Sarajevo, Middle Bosnia, Una - Sana, and Herzegovina - Neretva Cantons. In neonatal institutions of the 1st level, 29/1651 preterm infants were born, while in the neonatal institutions of the $2^{\text {nd }}$ level 286/9490 infants were born. Preterm infant rate between the institutions of the 1 st and the $2^{\text {nd }}$ level is significantly different between these institutions and the institutions of the $3^{\text {rd }}$ level.

At the beginning of the regionalization of perinatal care (1970-1985) in the USA, relatively small number of preterm infants was born in the $3^{\text {rd }}$ level institutions. Comparing our results with currently available reports from the countries with existing regionalized pe- rinatal care, the preterm LBW infant rates in $\mathrm{FB} \& \mathrm{H}$ are low (8). Regionalization is a regulatory approach to rationalization of resource allocation, especially for highly specialized medical services or technologies. Proposals to encourage regionalization have waxed and waned in popularity over the years. A major argument in favour of regionalization is the possibility of achieving better patient outcomes. Experiences in regionalizing perinatal and neonatal care have resulted in improved outcomes for mothers and infants (13).

The limitation of our study is that it was not taking into account the differences between the regionalized and non regionalized institutions which are treating sick newborns like paediatric trauma centres and neonatal intensive care units.

\section{CONCLUSION}

It would be ideal that every high risk pregnant woman is transferred to the institution of appropriate organisational level before delivery. Unfortunately, it is not always possible to predict the delivery of high risk infants, which makes transport "in utero" not always possible. In these circumstances post-natal transport of severely sick newborn is mandatory. The existing regionalization of perinatal care in the FB\&H significantly affects the mortality of preterm infants. Survival rate of infants born in the institutions of the $3^{\text {rd }}$ level was statistically much higher than the survival rate of infants who were born in the $1^{\text {st }}$ and the $2^{\text {nd }}$ level institutions.
Abbreviations
PHI - Perinatal Healthcare Institutions
LBW - Low Birth Weight
FB\&H - Federation of Bosnia and Herzegovina

\title{
Sažetak
}

\section{PERINATALNI ISHOD NEDONOŠČCDI U FEDERACIJI BOSNE I HERCEGOVINE}

\author{
Skokić Fahrija, ${ }^{1}$ Hotić Nesad, ${ }^{1}$ Muratović Selma, ${ }^{2}$ Skokić Maida, ${ }^{1}$ Hadžić Devleta, ${ }^{1}$ \\ Cosićkić Almira, ${ }^{1}$ Selimović Amela, ${ }^{1}$ Zulić Evlijana, ${ }^{1}$ Merić Alma, Halilbašić Amir ${ }^{1}$

\footnotetext{
${ }^{1}$ Klinika za dječije bolesti, Univerzitetski klinički centar Tuzla, Medicinski fakultet u Tuzli, Bosna i Hercegovina

${ }^{2}$ Klinika za ginekologiju i akušerstvo, Univerzitetski klinički centar Tuzla, Medicinski fakultet u Tuzli, Bosna i Hercegovina
}

Uvod: Uprkos napretku perinatalne medicine i nege, svake godine se rodi $9-19 \%$ nedonoščadi. Poboljšanje preživljavanja takve novorođenčadi i smanjenje neonatalnog mortaliteta je ključno u kvalitetu perinatalne zdravstvene nege.

Cilj studije: Evaluirati perinatalni ishod nedonoščadi u porodilištima u Federaciji Bosne i Hercegovine u jednogodišnjem periodu.
Ispitanici i metodi: Od ukupno 22897 novorodenčadi, ulazne kriterijume je zadovoljilo $669(2,9 \%)$ nedonoščadi sa kompletnom zdravstvenom dokumentacijom u 10 kantona Federacije Bosne i Hercegovine. Analizirali smo podatke iz porodilišta i otpusne liste iz tercijarnih zdravstvenih centara.

Rezultati: Najviše porođaja je bilo u Tuzlanskom i Sarajevskom kantonu sa 42,5\% nedonoščadi. Srednja 
gestaciona dob nedonoščadi je iznosila 31,4 sedmica, $\mathrm{sa} \mathrm{SD} \pm 5.34$ i srednjom porođajnom masom od 1295 grama, $\mathrm{SD} \pm 234.2$. Srednja vrednost Apgar skora je iznosila $4.6 \pm 2.1$ u prvoj minuti, a $6.6 \pm 1.9$ u petoj minuti. Od ukupno 669 ispitanika, bilo je 345 (51.56\%) muškog pola i $324(48.44 \%)$ ženskog pola (51.56 vs $48.44 ; \div 2=1.19 ; \mathrm{P}=0.27)$. Analizirajući frekvencu rađanja nedonoščadi prema porođajnoj masi, pronašli smo značajnu razliku u različitim nivoima perinatalnih zdravstvenih ustanova, između prvog i drugog institucionalnog nivoa $(1.76 \%$ vs $3.01 \%$; $\mathrm{P}<0.0001)$, kao i

\section{REFERENCES}

1. Fiscella K. Race, genes and preterm delivery. J Natal Med Assoc 2005; 97(11): 1516-26.

2. Thorsen P, Schendel DE, Deshpande AD, Vogel I, Dudley DJ, Olsen J. Identification of biological/biochemical marker(s) for preterm delivery. Paediatr Perinat Epidemiol 2001; 15 (Suppl 2): 90-103.

3. Horbar JD, Badger GJ, Carpenter JH, et al. Trends in mortality and morbidity for very low birth weight infants, 1991-1999. Pediatrics. 2002; 110 (1 Pt 1): 143-51.

4. Mathews TJ, MacDorman MF. Infant mortality statistics from the 2005 period linked birth/infant death data set. Natl Vital Stat Rep. 2008; 57(2): 1-32.

5. Regev RH, Lusky A, Dolfin T et al. Excess mortality and morbidity among small-for-gestational-age premature infants: a population-based study. J Pediatr 2003; 143(2): 186-91.

6. Bartels DB, Kreienbrock L, Dammann O, Wenzalff P,Poets CF. Population based study of small for gestational age newborns. Arch Dis Child Fetal Neonatal Ed 2005; 90(1): 53-9.

7. Warner B, Musial MJ, Chenier T, Donovan E. The effect ofbirth hospital type on the outcome of very low birth weight infants. Pediatrics. 2004; 113 (1 Pt 1): 35-41.

\section{Correspondence to/Autor za korespondenciju}

Fahrija Skokić

Paediatric Clinic University Clinical Centre Tuzla

Trnovac bb. 75000 Tuzla

Bosnia and Herzegovina

Tel.: +38761152351

e-mail: fskokic@hotmail.com između drugog i trećeg institucionalnog nivoa (3.01\% vs $3.03 \%$; $\mathrm{P}<0.0002)$, te između prvog i trećeg institucionalnog nivoa ( $1.76 \%$ vs $3.03 \% ; \mathrm{P}<0.0001)$.

Zaključak: Perinatalni ishod nedonoščadi u Federaciji Bosne i Hercegovine značajno zavisi od nivoa perinatalne zdravstvene ustanove. Stopa preživljavanja nedonoščadi rođenih u instituciji trećeg nivoa je bila značajno veća od stope preživljavanja nedonoščadi rođenih u perinatalnim institucijama prvog i drugog nivoa.

Ključne reči: nedonoščad, perinatalni ishod, prevremeno rođenje, regionalizacija, neonatalni mortalitet.

8. Lee HC, Green C, Hintz SR, et al. Predicition of death for extremely premature infants in a population-based cohort. Pediatrics. 2010; 126(3): 644-50.

9. Kollée LA, den Ouden AL, Drewes JG, Brouwers HA, Verwey RA, Verloove-Vanhorick SP. Increase in perinatal referral to regional centers of premature birth in The Netherlands: comparison 1983 and 1993. Ned Tijdschr Geneeskd. 1998; 142(3): 131-4.

10. Rosenblatt RA, Macfarlane A, Dawson AJ, Cartlidge PH, Larson EH, Hart LG. The regionalization of perinatal care in Wales and Washington State. Am J Public Health. 1996; 86(7): 1011-5.

11. Association of Neonatologists and NICU experts of the Federation of Bosnia and Herzegovina. [homepage on the Internet]. Available from: http://www.unif.ba.

12. Department of Reproductive Health and Research, World Health Organization [homepage on the Internet]. Global Monitoring and evaluation. c2004 - [cited 2010 December 20]. Available from: http://www.who.int/reproductivehealth/global_monitoring/skilled_attendant.html/.

13. American Academy of Pediatrics. Committee on Pediatric Emergency Medicine. American College of Critical Care Medicine. Society of Critical Care Medicine. Consensus report for regionalization of services for critically ill or injured children. Pediatrics.2000; 105 (1 Pt 1): 152-5. PMid:10617722. 